\title{
PERKEMBANGAN EMOSI DAN SOSIAL PADA ANAK USIA SEKOLAH DASAR
}

\author{
Ilham \\ STKIP Yapis Dompu \\ Email: ilhamtarbiyah@gmail.com
}

\begin{abstract}
Abstrak
Perkembangan manusia merupakan proses yang kompleks, yang dapat dibagi menjadi empat ranah utama, yaitu perkembangan fisik, intelektual, (termasuk kognisi dan bahasa), serta emosi dan sosial (termasuk perkembangan moral. Pada tulisan artikel ini penulis akan mengkaji tentang perkembangan emosi dan sosial pada anak usia sekolah dasar. Perkembangan emosi dan sosial adalah kepekaan anak untuk memahami perasaan orang lain ketika berinteraksi dalam kehidupan sehari-hari. Perkembangan sosial-emosional ini sejatinya tidak dapat dipisahkan satu sama lain. Ketika membahas perkembangan sosial anak maka harus bersinggungan dengan perkembangan emosi anak.
\end{abstract}

Kata Kunci: Perkembangan Emosi, Sosial, Anak SD

\section{PENDAHULUAN}

erkembangan adalah proses perubahan yang terjadi pada
manusia yaitu proses bertambahnya kemampuan menjadi lebih
baik ataupun sebaliknya, begitu juga dengan perkembangan anak. Bertambahnya kemampuan anak, baik dilihat dari postur tubuh, fungsi tubuh yang lebih sempurna. Perkembangan menyangkut adanya perubahan dari sel-sel tubuh, jaringan tubuh, organ-organ, dan sistem organ yang berkembang sedemikian rupa sehingga masing-masing dapat memenuhi fungsinya.

Kemampuan seperti itu tidak bisa dicapai begitu saja, tetapi perlu upaya yang dilakukan sejak anak masih kecil. Penguasaan berbagai kemampuan yang memadai akan menghantarkan individu meraih keberhasilan dalam kehidupan. Untuk menunjang keberhasilan individu dalam hidup maka sejak kecil anak perlu menguasai berbagai kemampuan terutama kemampuan sosial emosional yang baik. Kemampuan sosial emosional merupakan pondasi bagi perkembangan kemampuan anak berinteraksi dengan lingkungannya secara lebih luas. Seorang tidak hanya dituntut untuk mampu berinteraksi secara baik dengan orang lain, tetapi terkait juga didalamnya bagaimana ia mampu mengendalikan dirinya secara baik. Ketidakmampuan individu 
mengendalikan dirinya dapat menimbulkan berbagai masalah sosial emosional dengan orang lain.

\section{TINJAUAN TEORITIS}

Konsep Perkembangan Emosi Anak

1. Pengertian Perkembangan Emosi

Perkembangan secara termitologis adalah proses kualitatif yang mengacu pada penyempurnaan fungsi sosial dan psikologis dalam diri seseorang dan berlangsung sepanjang hidup (Retno Wulandari dkk, 2016). Perkembangan ialah proses perubahan kuantitatif yang mengacu pada mutu fungsi organ-organ jasmaniah, bukan organ jasmaniahnyaitu sendiri (Muhibbin, 2009). Dengan kata lain, penekanan arti perkembangan itu terletak pada penyempurnaan fungsi psikologis yang disandang oleh organ-organ fisik. Perkembangan akan berlanjut terus hingga manusia mengakhiri hayatnya.

Mutiah mengatakan "perkembangan anak usia dini merupakan konsep yang memiliki perubahan yang bersifat kuantitatif yang menyangkut aspek mental/psikologis (Nurhabibah dkk, 2016). Kemampuan anak dalam merespon pembicaraan orang tua, tawa orang dewasa, merangkak, berjalan, memengang suatu benda, dan sebagainya". Oleh karena itu, hubungan sosial sangat penting dalam perkembangan anak. Perkembangan dapat diartikan juga sebagai perubahan yang bersifat progresif dan kontinyu (berkesinabungan) dalam diri induvidu dari mulai lahir sampai mati (Syamsul Yusuf, 2014).

Berdasarkan pendapat di atas dapat di simpulkan bawa perkembangan adalah proses perubahan yang terjadi pada manusia yaitu proses bertambahnya kemampuan menjadi lebih baik ataupun sebaliknya, begitu juga dengan perkembangan anak. Bertambahnya kemampuan anak, baik dilihat dari postur tubuh, fungsi tubuh yang lebih sempurna. Perkembangan menyangkut adanya perubahan dari 
sel-sel tubuh, jaringan tubuh, organ-organ, dan sistem organ yang berkembang sedemikian rupa sehingga masing-masing dapat memenuhi fungsinya.

Istilah emosi berasal dari kata emotus atau emovere atau mencerca (to stir up) yang berarti sesuatu yang mendorong terhadap sesuatu, misal emosi gembira mendorong untuk tertawa, atau dengan perkataan lain emosi didefinisikan sebagai suatu keadaan gejolak penyesuaian diri yang berasal dari dalam dan melibatkan hamper keseluruhan diri individu. Menurut Sarlito Wirawan Sartono berpendapat bahwa emosi merupakan setiap keadaan pada diri seseorang yang disertai warna afekti (Heleni Fitri, 2018). Yang dimaksud warna efektif ini adalah perasaan-perasaan tertentu yang dialami pada saat menghadapi (menghayati) suatu situasi tertentu contohnya: gembira, bahagia, takut dan lain-lain. Sedangkan menurut Goleman Bahasa emosi merujuk pada suatu perasaan atau pikiran. Pikiran khasnya, suatu keadaan biologis dan psikologis serta rangkaian kecenderungan untuk bertindak .

Berdasarkan pendapat dari para ahli di atas maka dapat disimpulkan bahwa emosi adalah suatu keadaan yang ada pada diri seseorang yang memberi warna atau rasa (perasaan) bahagia, takut maupun senang dan lain-lain. Sedangkan Emosi dalam makna paling harfiah, Oxford english Dictionary mendefinisikan sebagai "setiap kegiatan atau pergolakan pikiran, perasaan, nafsu, setiap keadaan mental yang hebat atau meluap-luap". Saya menganggap emosi merujuk pada suatu perasaan dan pikiran-pikiran khasnya, suatu keadaan biologis dan psikologis, dan serangkaian kecenderungan untuk bertindak (Daniel Goleman, 2002).

Perkembangan emosi adalah suatu keadaan yang kompleks dapat berupa perasaan pikiran yang di tandai oleh perubahan biologis 
yang muncul dari perilaku seseorang baik itu berupa nafsu, perasaan maupun keadaan mental yang tidak terkontrol.

2. Indikator Perkembangan Emosional Anak Usia Dini

Menurut Kementrian Pendidikan Nasional tentang peraturan menteri pendidikan dan kebudayaan Republik Indonesia Nomor 137 tahun 2013 indikator tingkat percapaian perkembangan anak usia 5-6 tahun adalah sabagai berikut (Kemendikbud, 2015):

Tabel Indikator Perkembangan Emosional Anak Usia Dini

\begin{tabular}{|c|c|}
\hline Lingkup Perkembangan & $\begin{array}{l}\text { Indikator Tingkat Pencapaian } \\
\text { Perkembangan Anak Usia5-6 Tahun }\end{array}$ \\
\hline $\begin{array}{l}\text { - Emosional } \\
\text { Dapat menunjukkan } \\
\text { emosi yang wajar }\end{array}$ & $\begin{array}{l}\text { 1. Mau berpisah dengan ibu } \\
\text { 2. Menerima kritikan dan saran } \\
\text { 3. Membantu memecahkan perselisihan/masalah } \\
\text { 4. Mengekpresikan perasaannya (Misal: Marah, } \\
\text { sedih, gembira, kaget, dll }\end{array}$ \\
\hline $\begin{array}{l}\text { Terbiasa } \\
\text { menunjukkan sikap } \\
\text { kedisplinan dan } \\
\text { mentaati peraturan }\end{array}$ & $\begin{array}{l}\text { 1. Membuang sampah pada tempatnya } \\
\text { 2. Merapikan mainan setelah digunakan } \\
\text { 3. Mentaati peraturan yang berlaku } \\
\text { 4. Berangkat ke sekolah tepat waktu }\end{array}$ \\
\hline $\begin{array}{l}\text { Dapat bertanggung } \\
\text { jawab }\end{array}$ & $\begin{array}{l}\text { 1. Melaksanakan tugas yang diberikan guru. } \\
\text { 2. Menjaga barang milik sendiri dan orang lain } \\
\text { 3. Melaksanakan kegiatan sendiri sampai selesai } \\
\text { 4. Bertanggung jawab terhadap tugas yang } \\
\text { diberkan } \\
\text { 5. Memelihara milik sendiri } \\
\text { 6. Bekerjasama dalam menyelesaikan tugas }\end{array}$ \\
\hline $\begin{array}{l}\text { Terbiasa menjaga } \\
\text { lingkungan }\end{array}$ & $\begin{array}{l}\text { 1. Memelihara lingkungan. Misalnya: tidak } \\
\text { mencorat coret tembok, membuang sampah } \\
\text { pada tempatnya, dll. } \\
\text { 2. Menghemat pemakaian air dan listrik } \\
\text { 3. Membersihkan peralatan makanan setelah } \\
\text { digunakan }\end{array}$ \\
\hline
\end{tabular}


3. Perkembangan Emosional Anak Usia Dini

Perkembangan emosi pada anak dini melalui beberapa fase yaitu:

a. Pada bayi hingga 18 bulan

1) Pada fase ini, bayi butuh belajar dan mengetahui bahwa lingkungan di sekitarnya aman dan familier. Perlakuan yang diterima pada fase ini berperan dalam membentuk rasa percaya diri, cara pandangnya terhadap orang lain serta interaksi dengan orang lain. Contoh ibu yang memberikan ASI secara teratur memberikan rasa aman pada bayi.

2) Pada minggu ketiga atau keempat bayi mulai tersenyum jika ia merasa nyaman dan tenang. Minggu ke delapan ia mulai tersenyum jika melihat wajah dan suara orang di sekitarnya.

3) Pada bulan keempat sampai kedelapan bayi mulai belajar mengekspresikan emosi seperti gembira, terkejut, marah dan takut. Pada bulan ke-12 sampai 15, ketergantungan bayi pada orang yang merawatnya akan semakin besar. Ia akan gelisah jika ia dihampiri orang asing yang belum dikenalnya. Pada umur 18 bulan bayi mulai mengamati dan meniru reaksi emosi yang di tunjukan orangorang yang berada di sekitar dalam merespon kejadian tertentu.

b. 18 bulan sampai 3 tahun

1) Pada fase ini, anak mulai mencari-cari aturan dan batasan yang berlaku di lingkungannya. Ia mulai melihat akibat perilaku dan perbuatannya yang akan banyak mempengaruhi perasaan dalam menyikapi posisinya di lingkungan. Fase ini anak belajar membedakan cara benar dan salah dalam mewujudkan keinginannya.

2) Pada anak usia dua tahun belum mampu menggunakan banyak kata untuk mengekspresikan emosinya. Namun ia akan 
memahami keterkaitan ekspresi wajah dengan emosi dan perasaan. Pada fase ini orang tua dapat membantu anak mengekspresikan emosi dengan bahasa verbal. Caranya orang tua menerjemahkan mimik dan ekspresi wajah dengan bahasa verbal.

3) Pada usia antara 2 sampai 3 tahun anak mulai mampu mengekspresikan emosinya dengan bahasa verbal. Anak mulai beradaptasi dengan kegagalan, anak mulai mengendalikan prilaku dan menguasai diri.

c. Usia antara 3 sampai 5 tahun

1) Pada fase ini anak mulai mempelajari kemampuan untuk mengambil inisiatif sendiri. Anak mulai belajar dan menjalin hubungan pertemanan yang baik dengan anak lain, bergurau dan melucu serta mulai mampu merasakan apa yang dirasakan oleh orang lain.

2) Pada fase ini untuk pertama kali anak mampu memahami bahwa satu peristiwa bisa menimbulkan reaksi emosional yang berbeda pada beberapa orang. Misalnya suatu pertandingan akan membuat pemenang merasa senang, sementara yang kalah akan sedih.

d. Usia antara 5 sampai 12 tahun

1) Pada usia 5-6 anak mulai mempelajari kaidah dan aturan yang berlaku. Anak mempelajari konsep keadilan dan rahasia. Anak mulai mampu menjaga rahasia. Ini adalah keterampilan yang menuntut kemampuan untuk menyembunyikan informasiinformasi secara.

2) Anak usia 7-8 tahun perkembangan emosi pada masa ini anak telah menginternalisasikan rasa malu dan bangga. Anak dapat menverbalsasikan konflik emosi yang dialaminya. Semakin 
bertambah usia anak, anak semakin menyadari perasaan diri dan orang lain.

3) Anak usia 9-10 tahun anak dapat mengatur ekspresi emosi dalam situasi sosial dan dapat berespon terhadap distress emosional yang terjadi pada orang lain. Selain itu dapat mengontrol emosi negatif seperti takut dan sedih. Anak belajar apa yang membuat dirinya sedih, marah atau takut sehingga belajar beradaptasi agar emosi tersebut dapat dikontrol.

4) Pada masa usia 11-12 tahun, pengertian anak tentang baikburuk, tentang norma-norma aturan serta nilai-nilai yang berlaku di lingkungannya menjadi bertambah dan juga lebih fleksibel, tidak sekaku saat di usia kanak-kanak awal. Mereka mulai memahami bahwa penilaian baik-buruk atau aturanaturan dapat diubah tergantung dari keadaan atau situasi munculnya perilaku tersebut. Nuansa emosi mereka juga makin beragam.

4. Faktor-faktor yang Mempengaruhi Perkembangan Emosi

a. Keadaan anak

Keadaan individu pada anak, misalnya cacat tubuh ataupun kekurangan pada diri anak akan sangat mempengaruhi perkembangan emosional, bahkan akan berdampak lebih jauh pada kepribadian anak. Misalnya: rendah diri, mudah tersinggung, atau menarik diri dari lingkunganya.

b. Faktor belajar

Pengalaman belajar anak akan menentukan reaksi potensial mana yang mereka gunakan untuk marah. Pengalaman belajar yang menunjang perkembangan emosi antara lain:

1) Belajar dengan coba-coba Anak belajar dengan coba-coba untuk mengekspresikan emosinya dalam bentuk perilaku yang 
memberi pemuasan sedikit atau sama sekali tidak memberi kepuasan.

2) Belajar dengan meniru

Dengan cara meniru dan mengamati hal-hal yang membangkitkan emosi orang lain, anak bereaksi dengan emosi dan metode yang sama dengan orang-orang yang diamati.

3) Belajar dengan mempersamakan diri

Anak meniru reaksi emosional orang lain yang tergugah oleh rangsangan yang sama dengan rangsangan yang telah membangkitkan emosi orang yang ditiru. Disini anak hanya meniru orang yang dikagumi dan mempunyai ikatan emosional yang kuat dengannya.

4) Belajar melalui pengondisian

Dengan metode ini objek, situasi yang mulanya gagal memancing reaksi emosional kemudian berhasil dengan cara asosiasi. Pengondisian terjadi dengan mudah dan cepat pada awalawal kehidupan karena anak kecil kurang menalar, mengenal betapa tidak rasionalnya reaksi mereka.

5) Belajar dengan bimbingan dan pengawasan.

Anak diajarkan cara bereaksi yang dapat diterima jika suatu emosi terangsang. Dengan pelatihan, anak-anak dirangsang untuk bereaksi terhadap rangsangan yang biasanya membangkitkan emosi yang menyenangkan dan dicegah agar tidak bereaksi secara emosional terhadap rangsangan yang membangkitkan emosi yang tidak menyenangkan (Fatimah, 2006)

c. Konflik - konflik dalam proses perkembangan

Setiap anak melalui berbagai konflik dalam menjalani fasefase perkembangan yang pada umumnya dapat dilalui dengan 
sukses. Namun jika anak tidak dapat mengamati konflik-konflik tersebut, biasanya mengalami gangguan-gangguan emosi.

d. Lingkungan keluarga

Salah satu fungsi keluarga adalah sosialisasi nilai keluarga mengenai bagaimana anak bersikap dan berperilaku. Keluarga adalah lembaga yang pertama kali mengajarkan individu (melalui contoh yang diberikan orang tua) bagaimana individu mengeksplorasi emosinya. Keluarga merupakan lingkungan pertama dan utama bagi perkembangan anak. Keluarga sangat berfungsi dalam menanamkan dasar-dasar pengalaman emosi, karena disanalah pengalaman pertama didapatkan oleh anak. Keluarga merupakan lembaga pertumbuhan dan belajar awal (learning and growing) yang dapat mengantarkan anak menuju pertumbuhan dan belajar selanjutnya.

Gaya pengasuhan keluarga akan sangat berpengaruh terhadap perkembangan emosi anak. Apabila anak dikembangkan dalam lingkungan keluarga yang emosinya positif, maka perkembangan emosi anak akan menjadi positif. Akan tetapi, apabila kebiasaan orang tua dalam mengekspresikan emosinya negatif seperti, melampiaskan kemarahan dengan sikap agresif, mudah marah, kecewa dan pesimis dalam menghadapi masalah, maka perkembangan emosi anak akan menjadi negatif.

Berdasarkan penjelasan di atas maka dapat di simpulkan secara sederhana tentang perkembangan emosional anak usia dini. Istilah emosi berasal dari kata emotus atau emovere atau mencerca (to stir up) yang berarti sesuatu yang mendorong terhadap sesuatu, misal emosi gembira mendorong untuk tertawa, atau dengan perkataan lain emosi didefinisikan sebagai suatu keadaan gejolak penyesuaian diri yang berasal dari dalam dan melibatkan hamper keseluruhan diri individu. Sedangkan Emosi dalam makna paling 
harfiah, Oxford english Dictionary mendefinisikan sebagai "setiap kegiatan atau pergolakan pikiran, perasaan, nafsu, setiap keadaan mental yang hebat atau meluap-luap". Saya menganggap emosi merujuk pada suatu perasaan dan pikiran-pikiran khasnya, suatu keadaan biologis dan psikologis, dan serangkaian kecenderungan untuk bertindak. Sehingga perkembangan emosi adalah suatu keadaan yang kompleks dapat berupa perasaan pikiran yang di tandai oleh perubahan biologis yang muncul dari perilaku seseorang baik itu berupa nafsu, perasaan maupun keadaan mental yang tidak terkontrol.

Indikator-indikator perkembangan emosi anak usia dini seperti dapat menunjukkan emosi yang wajar, Terbiasa menunjukkan sikap kedisplinan dan mentaati peraturan, serta dapat bertanggung jawab di setiap perilakunya. Perkembangan emosional anak usia dini melalui beberapa tahapan usia, mulai dari usia 18 bulan anak mulai belajar mengenal lingkungan sekitar dan kelurganya sampai pada tahap usia 5-12 tahun. Seorang anak belajar menaati aturan dan kaidah yang berlaku dalam lingkungannya.

\section{Konsep Perkembangan Sosial Anak}

1. Pengertian Perkembangan Sosial

Plato secara potensial (fitrah) manusia dilahirkan sebagai makhluk sosial (zoon politicon) (Yeni Rahmawati, 2018). Syamsuddin mengungkapkan bahwa "sosialisasi adalah proses belajar untuk menjadi makhluk sosial”, sedangkan menurut Loree "sosialisasi merupakan suatu proses di mana individu (terutama) anak melatih kepekaan dirinya terhadap rangsangan-rangsangan sosial terutama tekanan-tekanan dan tuntutan kehidupan (kelompoknya) serta belajar bergaul dengan bertingkah laku, seperti orang lain di dalam lingkungan sosialnya”. 
Hurlock mengutarakan bahwa perkembangan sosial merupakan perolehan kemampuan berperilaku yang sesuai dengan tuntutan sosial. "Sosialisasi adalah kemampuan bertingkah laku sesuai dengan norma, nilai atau harapan sosial". Perkembangan sosial adalah suatu proses pembentukan social self (pribadi dalam masyarakat) oleh seseorang untuk memperoleh kemampuan berperilaku yang sesuai dengan norma dan nilai lingkungan sosialnya (Nurul Istiqamah dkk, 2016).

Berdasarkan pengertian diatas perkembangan sosial adalah preses pembentukan kepribadian seseorang untuk memperoleh kemampuan berprilaku yang sesuai dengan norma dan nilai yang berlaku di lingkungan sosial.

2. Tahapan Perkembangan Sosial Anak

Perkembangan sosial merupakan perkembangan tingkah laku pada anak dimana anak diminta untuk menyesuaikan diri dengan aturan yang berlaku dalam lingkungan masyarakat. Dengan kata lain, perkembangan sosial merupakan proses belajar anak dalam menyesuaikan diri dengan norma, moral dan tradisi dalam sebuah kelompok (Femmi Nurmalitasari, 2015). Menurut Catherine Lee dalam Hasnida tahapan perkembangan sosial anak di mulai sejak ia dilahirkan atau dengan perkataan lain sejak terjadi interaksi antara anak sebagai individu dengan orang-orang yang berada disekitarnya. Berikut diuraikan berbagai perilaku sosial anak berdasarkan tahapan usia perkembangan:

a. Pasca lahir

Anak lebih suka ditinggalkan tanpa diganggu, merasa senang waktu berkontak erat dengan tubuh ibu, menangis keras apabila merasa tidak enak, tetapi bila didekap erat, diayun demgan lembut anak akan berhenti menangis (Rima Agustiana, 2018). 
b. Satu bulan sampai tiga bulan

Merasakan kehadiran ibu dan memandang kearahnya bila ibu mendekati. Terus menerus mengamati setiap gerakan orang yang berada didekatnya, berhenti menangis bila diajak bermain atau bicara oleh siapa saja yang bersikap ramah.

c. Enam bulan

Penuh minat terhadap segala sesuatu yang sedang terjadi disekitarnya, jika akan diangkat anak akan mengulurkan kedua tangannya. Tertawa kecil bila diajak bermain, walaupun biasanya bersahabat tetapi tidak langsung menyambut dan memberi respon terhadap orang yang tidak dikenalnya.

d. Sembilan bulan sampai dua belas bulan

Mengerti kata tidak, melambaikan tangan, bertepuk tangan atau menggoyangkan tangan mengikuti nyanyian. Bermain dengan orang dewasa yang dikenal dan memperhatikan serta meniru tindakan orang dewasa, mulai memahami dan mematuhi perintah sederhana.

e. Delapan belas bulan sampai dua puluh satu bulan

Ketergantungan terhadap orang lain dalam hal bantuan, perhatian kasih sayang. Mengerti sebagian apa yang dikatakan kepada dirinya dan mengulangi kata yang diucapkan orang dewasa.

f. Dua tahun sampai dua setengah tahun

Mempunyai minat yang besar dalam hal mengumpulkan katakata, mulai banyak bertanya dan bisa menunjukan ciri dan sebagian anggota tubuh apabila ditanya, senang mendapatkan persetujuan orang dewasa dan banyak bercakap-cakap.

g. Tiga tahun sampai lima tahun

Berbicara bebas pada dirinya, orang lain bahkan mamanya, berbicara dengan lancar, bermain dengan kelompok. Anak kadang 
merasa puas bila bermain sendiri untuk waktu yang lama dan mulai menyenangi kisah seorang/tokoh dalam film.

3. Faktor-faktor yang mempengaruhi perkembangan sosial anak usia dini adalah sebagai berikut:

a. Faktor Keluarga

1) hubungan orang tua, antar saudara, antar anak dengan orangtua, hubungan anak dengan orangtua ataupun saudara akan terjalin rasa kasih sayang, dimana anak akan lebih terbuka dalam melakukan interaksi karena terjadinya hubungan yang baik yang ditunjang oleh kominikasi yang tepat. Perang orang tua akan membimbing anak untuk mengenal lingkungan sekitar tempat tinggalnya.

2) Urutan anak dalam keluarga (sulung tengah bungsu)

Urutan anak dalam keluarga berpengaruh pada anak misalnya sang anak merupakan anak terakhir maka dipastikan sang anak bergantung pada orangtua dan saudaranya. Jika hal ini terjadi akan berpengaruh pada tingkat kemandirian anak tersebut.

3) Jumlah keluarga

Pada dasarnya jumlah anggota yang besar berbeda dengan jumlah anggota yang sedikit. Jika dalam suatu keluarga mempunyai anak yang sedikit, maka perhatian, waktu dan kasih sayang lebih banyak tercurahkan, dimana segala bentuk aktivitas dapat di temani ataupun dibantu, hal ini berbeda dengan keluarga yang besar.

4) Perlakukan keluarga terhadap anak

Adanya perlakuakn keluarga terhadap anak prasekolah secara langsung mempengaruhi pribadi dan gerakan sang anak. Dimana dalam keluaraga tertanam rasa saling perhatian, tidak kasar dan selalu merespon setiap kegiatan anak, maka dapat 
berpengaruh terhadap perkembangan anak yang lebih baik dan terarah.

5) Harapan orangtua terhadap anak

Setiap orangtua memiliki harapan mempunyai anak yang baik, cerdas dan terarah dalam masa depannya. Harapan orangtua mempunyai anak yang memiliki perkembanagan pra sekolah yang sekolah bertujuan mempunyai arah sesuai perkembangannya.

b. Faktor diluar keluarga

1) Interaksi dengan tema sebaya

Setiap anak jika mempunyai perkembangan yang baik maka secara alami dapat berinteraksi dengan temannya tampa harus disuruh atau ditemani keluarga karena anaka memiliki arahan yang jelas.

2) Hubungan dengan orang dewasa diluar rumah

Jika seorang anak selalu diperkenalkan dengan lingkungan luar dan diberi arahan bergaul dengan siapa saja maka sang anak dapat menyusuiakan lingkungan orang dewasa dimana anak tampa malu-malu berinteraksi dengan orang yang lebih dewasa dari dirinya.

c. Faktor Pengaruh Pengalaman Sosial Anak

Jika seorang anak memiliki pengalaman sosial yang buruk, seperti tidak diperbolehkan main keluar rumah oleh orang tuanya, maka hal itu, akan berpengaruh bagi proses sosialisasinya kepada lingkungan sekitarnya yang berada di luar rumah. Hal ini, akan menyebabkan anak menjadi tidak tahu dan kurang bersosialisasi dengan lingkungan di luar rumah (Farida Mayar, 2013).

Sebagaimana dalam pembelajaran anak melalui interaksi sosial baik dengan orang dewasa maupun dengan teman sebaya yang ada dilingkungan nya. Salah satu cara anak belajar adalah 
dengan cara mengamati, meniru, dan melakukan. Orang dewasa dan teman-teman yang dekat dengan kehidupan anak merupakan objek yang diamati dan ditiru anak. Melalui cara ini anak belajar cara bersikap, berkomunilasi, berempati, menghargai atau pengetahuan dan keterampilan lainnya. Pendidikan dan orangorang dewasa di sekitar anak seharusnya peka dan menyadari bahwa dirinya sebagai model yang pantas untuk ditiru anak dalam berucap, bersikap, merespon anak dan orang lain, sehingga dapat membantu anak mengembangkan kemampuan berkomunikasi dan kematangan emosinya.

4. Realita perilaku sosial dan tidak sosial

Perilaku sosial dan tidak sosial yang sering dilakukan anak-anak pada umumnya adalah sebagai berikut (Dyah Fachriyyati, 2015):

a. Pola Sosial

1) Meniru

Untuk menyamakan dengan kelompok lain, anak meniru sikap dan perilaku orang yang dikagumi.

2) Persaingan

Keinginan untuk mengungguli dan mengalahkan orang lain sudah mulai tampak pada usia 4 tahun.

3) Kerja sama

Kegiatan kelompok mulai berkembang dan meningkat baik dalam frekuensi maupun lamanya berlangsung, bersamaan dengan meningkatnya kesempatan untuk bermain dengan anak lain.

4) Simpati

Simpati membutuhkan pengertian tentang perasaanperasaan dan emosi orang lain. Semakin banyak kontak bermain, semakin cepat simpati akan berkembang. 
5) Empati

Empati membutuhkan pengertian tentang perasaanperasaan dan emosi orang lain tetapi di samping itu juga membutuhkan kemampuan untuk membayangkan diri sendiri di tempat orang lain.

6) Dukungan sosial

Anak beranggapan bahwa perilaku nakal dan perilaku mengganggu merupakan cara untuk memperoleh dukungan dari teman-teman sebaya.

7) Membagi

Lambat laun sifat mementingkan diri sendiri berubah menjadi sifat murah hati. Anak yang pada waktu bayi memperolehkepuasan dari hubungan yang hangat erat dan personal dengan orang lain berangsur-angsur memberikan kasih sayang kepada orang di luar rumah.

b. Pola tidak sosial

1) Negativisme

Dapat disebut juga sikap melawan otoritas orang dewasa. Perlawanan fisik lambat laun akan berubah menjadi perlawanan verbal dan pura-pura tidak mendengar atau tidak mengerti permintaan orang dewasa.

2) Agresif

Serangan fisik mulai diganti dengan seranganserangan verbal dalam bentuk memaki atau menyalahkan orang lain.

3) Perilaku berkuasa

Perilaku berkuasa atau "merajai" akan semakin meningkat dengan bertambah banyaknya kesempatan untuk kontak sosial. Anak perempuan cenderung lebih manja daripada anak lakilaki. 
4) Memikirkan diri sendiri

Dengan meluasnya pengalaman anak, maka akan semakin berkurang juga perilaku memikirkan diri sendiri, tetapi perilaku murah hati juga masih tergolong sangat $\operatorname{minim}$

5) Mementingkan diri sendiri

Anak akan dapat cepat mengubah perilaku mementingkan diri sendiri tergantung pada banyaknya kontak dengan orang-orang di luar rumah.

6) Merusak

Semakin hebat amarah seorang anak, maka semakin besar juga tindakan merusaknya.

7) Pertentangan seks

Pada usia masuk sekolah dasar, anak laki-laki berperilaku agresif yang melawan anak perempuan.

8) Prasangka

Prasangka sosial timbul pertama-tama dari prasangka agama atau sosial ekonomi. Tetapi lebih lambat dari prasangka terhadap seks.

Berdasarkan penjelasan di atas maka dapat disimpulkan bahwa Perkembangan sosial adalah preses pembentukan kepribadian seseorang untuk memperoleh kemampuan berprilaku yang sesuai dengan norma dan nilai yang berlaku di lingkungan sosial. Menurut Catherine Lee dalam Hasnida tahapan perkembangan sosial anak di mulai sejak ia dilahirkan atau dengan perkataan lain sejak terjadi interaksi antara anak sebagai individu dengan orang-orang yang berada disekitarnya. Misalnya pada usia pasca lahir anak lebih suka di tinggal tampa di ganggu, usia satu sampai tiga tahun anak lebih suka dia ajak bermain dan bercanda, usia tiga sampai lima tahun anak mulai bebas bermain. 
Realitas pola perilaku anak ada yang berperilaku sosial dan ada yang berprilaku tidak sosial. Misalnya perilaku sosial anak mulai meniru, kerja sama, simpati, emapti, suka berbagi dan punya dukungan sosial. Sedangakan realitas pola prilaku tidak sosial misalnya seorang anak suka berpikir negatif, egois, merusak dan suka prasangka menunjukan prilaku yang tidak baik dalam kehidupan bersosial.

\section{SIMPULAN}

Perkembangan emosi adalah suatu keadaan yang kompleks dapat berupa perasaan pikiran yang di tandai oleh perubahan biologis yang muncul dari perilaku seseorang. Indikator-indikator perkembangan emosi anak usia dini seperti dapat menunjukkan emosi yang wajar, Terbiasa menunjukkan sikap kedisplinan dan mentaati peraturan, serta dapat bertanggung jawab di setiap perilakunya. Perkembangan emosional anak usia dini melalui beberapa tahapan usia, mulai dari usia 18 bulan anak mulai belajar mengenal lingkungan sekitar dan kelurganya sampai pada tahap usia 5-12 tahun. Seorang anak belajar menaati aturan dan kaidah yang berlaku dalam lingkungannya.

Perkembangan sosial adalah preses pembentukan kepribadian seseorang untuk memperoleh kemampuan berprilaku yang sesuai dengan norma dan nilai yang berlaku di lingkungan sosial. Realitas pola perilaku anak ada yang berperilaku sosial dan ada yang berprilaku tidak sosial. Misalnya perilaku sosial anak mulai meniru, kerja sama, simpati, emapti, suka berbagi dan punya dukungan sosial. Sedangakan realitas pola prilaku tidak sosial misalnya seorang anak suka berpikir negatif, egois, merusak dan suka prasangka menunjukan prilaku yang tidak baik dalam kehidupan bersosial. 


\section{DAFTAR PUSTAKA}

Daniel Goleman, Emotional Intelligence, Cet 12, Jakarta: PT Gramedia Pustaka Utama, 2002.

Dyah Fachriyyati, Perkembangan Sosial Emosional Anak ditinjauh dari Pemberian syair lagu di TK Tarbiyah Athfal Krapyak Jepara. Skripsi, UNNES, 2015.

Farida Mayar, Perkembangan Sosial Anak Usia Dini Sebagai Bibit Ungguluntu Masa Depan Bangsa, Jurnal Al-Ta'lim, Jilid 1, Nomor 6 November 20 13, hlm. 459-464,Nomor 6 November 20 13.

Femmi Nurmalitasari, Perkembangan Sosial Emosi pada Anak Usia Prasekolah, Buletin Psikologi Fakultas Psikolgi Universitas Gadjah Mada: 103 - 111- ISSN: 0854-7108. VOLUME 23, NO. 2, DESEMBER 2015

Heleni Filtri, Perkembangan Emosional Anak Usia Dini Usia 5-6 Tahun Ditinjau Dari Ibu Yang Bekerja, PAUD Lectura: Jurnal Pendidikan Anak Usia Dini, Vol 1, No 1, Oktober 2017.

http://kurikulumpaud.blogspot.com/2013/07/indikator-paud-kelompokumur-5-6-tahun.html. Diakses pada tanggal 20 Mei 2018

http://digilib.unimus.ac.id/files/disk1/104/jtptunimus-gdl-septianawi5158-3-bab2.pdf. Perkembangan Sosial Anak. Diakses pada tanggal 03 mei 2018. Pukul 16: 30, hlm. 25-27

Muhibbin, Psikologi Belajar, (Jakarta: Raja Grafindi Persada, 2009.

Nurhabibah,1) Anizar Ahmad, Erni Maidiyah , Perkembangan Sosial Emosiaonal Anak Melalui Interaksi Sosial dengan Teman Sebaya di PAUD Nurul Hidayah, Desa Lampuk, Kabupaten Aceh Besar, Jurnal Ilmiah Mahasiswa Pendidikan Anak Usia Dini, 1 (1):6067 Agustus 2016

Nurul Istiqomah, Misno A. Lathif, dan Khutobah, Peningkatan Perkembangan Sosial dan Emosional Melalui Kegiatan Outbound pada Anak Kelompok B di TK Asy-Syafa'ah Jember Tahun Pelajaran 2015/2016, JURNAL EDUKASI UNEJ, III (2): 19-21. 2016

Retno Wulandari, Burhannudin Ichsan, Yusuf Alam Romadhon, Perbedaan Perkembangan Sosial anak Usia 3-6 tahun denagn Pendidikan Usia Dini dan Tampa Pendidikan Usia Dini di Kecematan Peterongan, Biomedika, Volume 8 Nomor 1, Februari 2016

Rima Agustiana, Meningkatkan Perkembangan Sosial Anak Usia Dini melalui Metode Proyek pada Anak Kelompok B di TK Sayang Bunda Kelurahan Pijoan. Artikel Pdf.

Syamsul Yusuf, Psikologi Perkembangan Anak dan Remaja, Cet 14, Bandung: Remaja Rosdakarya, 2014.

Yeni Rachmawati, Modul 1 Perkembangan Sosial Emosional pada Anak Usia Taman Kanak-Kanak. Diakses pada tanggal 02 mei 2018. Pukul 01:06 